\title{
Assessment of Health Service Quality by Health Visitor Program: Field Research in Maysan Health Directorate
}

\author{
Dr. Ghani DahhamTanai AL-Zubaidi', Rawaa Abd Al-Qader Al-kaisi \\ ${ }^{1}$ University of Baghdad, College of Administration and Economics, Department of Business, Waziriyya, Baghdad, Iraq \\ ${ }^{2}$ Ministry of Health,General Inspector Office ,Rusafa, Bab Al-Muadham, Baghdad , Iraq
}

\begin{abstract}
The aim of the research was to evaluate the provided health services quality from the patients' perspective through the health visitor program in Maysan governorate. To achieve the research objectives, the two researchers used the questionnaire as a data collection tool, as well as interviews and field visits. The research sample included 53 patients, The Statistical Analysis Program (SPSS) was used for data analysis. The research main findings are to achieve a high level of satisfaction with the quality of the health services provided by the health visitor program. The research came out with a set of recommendations, the most important of which is the need to spread awareness of quality and its concepts and applications in the health sector in general and the services provided by the health visitor program in particular, with a view to health education, changing ideas and habits and focusing on correct behaviors.
\end{abstract}

Keywords: Quality of Health Services, Health Visitor Program

\section{Introduction}

Improving the health services reality is the main objective of any health system. This objective is based on two main indicators. The first indicator is to reduce the possible differences between individuals in facilitating their access to health services, which is called health justice. The second indicator is to achieve the best level of health services provided, which is called the quality of health, and the principle of achieving quality in health institutions has become a basic requirement for all countries and is confirmed by the directions of the World Health Organization (WHO), especially in the field of primary health care, which is the first line of defense for community health.

In this regard, policies and programs must be adopted that are appropriate to every environment for the provision of health care, especially in relation to the care of children and pregnant mothers and those suffering from transitional and chronic diseases.

The poor health situation in Maysan governorate has led public health officials to find new programs and policies to improve the quality of service. These policies resulted in the implementation of the health visitor program, which includes building a database through which to reach the targeted people of the health service throughout the governorate through mobile health visitor teams.The research included sex main sections: (Introduction, Research problem, Literature review, Research methodology, Results and Discussion, and finally Conclusions and Recommendations).

\section{Research Problem}

The research problem is the poor quality of health service provided and the use of useless, old and traditional policies by the primary health care centers in the province of
Maysan, which led to high numbers of deaths of children and mothers, and the increasing number of dropouts of vaccines, and increase the proportion of people with chronic and transitional diseases, As well as the lack of health awareness and all this made Maysan governorate the highest percentage of governorates in the health services deterioration, according to the annual report of the Ministry of Health for 2005, and the health visitor program to provide health services in primary health care centers to reduce this Lat, but not assessed this program can be summarized research problem through the following questions- :

2.1 To what extent does the health visitor program contribute to improving the provided health services quality in Maysan Governorate?

2.2 To what extent has the health visitor program contributed to reducing the health problems of children and mothers' death as well as those who have dropped out of vaccines?

2.3 What is the level of patient satisfaction with the health visitor program?

\section{Literature Review}

\subsection{Evaluation of health services quality}

The main objective of the quality of health services is to improve health programs and seek to improve and develop them. The most precise goal is to identify the strengths of the program and work to reinforce them and points of weakness to reduce them and work to overcome the same. Assessing the quality of health services is "relative" to new challenges (who, to whom, when, what and how)? Table (1) shows this.

\section{Volume 6 Issue 12, December 2017}




\section{International Journal of Science and Research (IJSR) \\ ISSN (Online): 2319-7064}

Index Copernicus Value (2016): 79.57 | Impact Factor (2015): 6.391

Table 1: Challenges of Quality Assessment of Health Services

\begin{tabular}{|c|c|}
\hline Indicator & Detail \\
\hline who & $\begin{array}{c}\text { Who evaluates health programs and what level of } \\
\text { quality they are achieving? }\end{array}$ \\
\hline To whom & To whom quality health services provided ? \\
\hline Where & Where to apply quality of health services? \\
\hline When & $\begin{array}{c}\text { When should the quality of the health service be } \\
\text { evaluated ? }\end{array}$ \\
\hline Why & Why is quality of service evaluated? \\
\hline How & How is quality of health services evaluated? \\
\hline $\begin{array}{c}\text { Reference : Based on Khoja, Tawfiq, 2003, Introduction to } \\
\text { Quality Improvement for Primary Health Care, Dar Al Shorouk } \\
\text { Publishing and Distribution, Amman, Jordan: 159-158. }\end{array}$ \\
\hline
\end{tabular}

\subsection{Measuring quality of health services}

The existence of a quality measure of honesty, accuracy, objectivity and consistency is essential to the success of the institution and in order to provide its services with the required quality. Several measures have been used to measure and evaluate the quality of health services : (Madi, 2002: 19)

\subsubsection{Measuring the quality of health services from the perspective of the service recipients.}

There are five basic ways to measure the quality of health services from the patients perspective as follows: - (Jauda, 2010: 79-98)

A - Scale of complaints number: This measure is to limit the number of complaints submitted by patients within a specified period of time, and these complaints express their dissatisfaction with the health service provided to them, or they do not meet their wishes and needs, or are below the required level.

B. Satisfaction Scale: It is one of the most widely used ways to measure patients' attitudes towards the quality of health services provided to them by using the Likert Scale, which measures the degree of importance of service standards from the patients point of view, but patient satisfaction may be achieved after appropriate treatment and the response to the guidelines or may not be achieved, and satisfaction can also be achieved as soon as he enters the health institution as a result of their care and attention and it may not be achieved as well.

C) Gap scale (Servqual model): This model is based on the basic dimensions reached by (Parasuraman and its colleagues) as a measure of service quality which are (tangible, guarantee, reliability, responsiveness and assurance) and presented as a general scale called Servqual , and this model is used twice, the first time before the patient gets the service to measure the so-called quality expected, and the second is measured after the service, which is known as perceived quality, and then determine the gap between these expectations and perceptions to measure the quality of service. (Idris, 2006: 13)

D) The actual performance measure (servperf): is called the trend model. Quality according to this model is a directional concept closely related to the patient's understanding of the actual performance of the service provided. This model focuses on perceptions when measuring and excludes expectations because they are unclear and difficult to measure. (2006 105).

E) Value measurement : The idea of the value measurement is the value that health service institutions provide to their customers depends on the benefit associated with their actual and perceived services by the patients and the cost of obtaining those services. The more the actual and perceived benefit of the service, the higher the value provide to customers, and accordingly demand for health services will increase and vice versa. (Al-Mahyawi, 2006: 105).

\subsubsection{Measuring the health services quality from a professional perspective}

The health services quality are measured from a professional perspective to three measures as follows : (Madkour, 1997: 233-234)

\section{a) Structural measures}

These standards adopt the idea that the proper structure or construction of health institutions and the equipment, systems and laws involved in providing the service, represent the essence and quality of the service. Although this approach is accepted by many researchers, the availability of structural standards is not sufficient to ensure the quality of health services . There are other complementary factors, such as ways of handling inputs and interaction between them.

\section{b) Quality measures in terms of operations}

This approach focuses on the various processes, activities, steps and stages of the production of services and providing them to beneficiaries. This approach consists of a set of criteria and indicators to be provided in specific percentages for all elements and activities of the services provided.

\section{c) Quality measures in terms of outputs (outcomes)}

These measures relate to final outcomes, reflecting net changes in health status as a product of health services provided which can be measured by measuring comparison (ie quantitative comparisons between target and actual performance) and the patient satisfaction survey list.

\subsubsection{Measuring quality from a comprehensive perspective (Jad Al-Rab, 2008: 331-332)}

The criteria mentioned above are mostly partial, which requires the need to find a measure that addresses the overall aspects. This is done by setting appropriate standards and developing them, preparing the survey forms in a scientific and high methodology, and directing these forms to customers, employees and any parties may have a relation to this service to study their satisfaction with the service, and any suggestions for improved service.

\subsection{Difficulties in the quality of health services in terms of identification, measurement and evaluation}

There are many difficulties that encountered the quality of health services, and will be analyzed as follows: (Almusaed, 2006: 24-31) (Abu Hasira, 2016: 72) 


\section{International Journal of Science and Research (IJSR) \\ ISSN (Online): 2319-7064}

Index Copernicus Value (2016): 79.57 | Impact Factor (2015): 6.391

3.3.1 Difficulties in determining the quality of health service

It is difficult to determine the quality of service provided to patients, because these services are intangible, and in order to deal with these problems, the health institutions should be concerned with the planning stage of their services, and that the Department seeks to stay and continue to achieve its objectives to compose a good reputation for continuity and growth.

\subsubsection{Difficulties in measuring quality of service}

It is difficult to measure the quality of the service provided by direct measurement, because there is a difference in the patient's perception of these services level. Also, the quality of the health service will not be measured according to the criteria that should actually be worked out, but measured according to the way they are performed. Service quality also can be measured by the high health level and social and economic changes of society.

\subsubsection{Difficulties in assessing the quality of health services}

The evaluation of health institutions differs from the evaluation of health institutions. The evaluation of health institutions depends on (patient satisfaction, employee satisfaction and the availability of medical devices and supplies). Services provided by health institutions can be evaluated through (3) elements (efficiency, effectiveness and cost).

\subsection{Health Visitor Program}

The process of health information automating and its electronic programming ensures that each family has a health card of which can receive health services with its preventive and therapeutic sides. Therefore, it is a qualitative leap in the level of health services and the preservation of information for all members of the family to facilitate access to all age groups, especially children under the age of five and mothers in the reproductive stage, thereby eliminating the phenomenon of dropouts of primary health care services. The program also aims to reduce patient and death rates for all age groups in general, children and mothers in particular, and increase community health awareness, as well as early detection of chronic diseases (diabetes, hypertension, etc.).

The program consists of a series of carefully planned actions, use of all resources available to implement the plans, use of modern technological means to build an integrated database, and work to develop and modernize that database. The health visitor as an (individual) is a trained health staff on the program's mechanisms and policies, they make population survey according to the geographic area in which they operate, and the provision of health services to all members of the community. , (Baseline assessment (USAID / PHCPI, Annual Report, 2012: 4) (report, 2011:3) (Aloraibi, 2008: 49-53).

\subsection{Health Visitor Program Objectives}

The health visitor program aims at improving primary health care services and ensuring the integration of the first, second and third levels of care. Table (2) shows the main objectives of the program and how to achieve them.
Table 2: Shows the main objectives of the program and how to achieve them

\begin{tabular}{|c|c|c|}
\hline 3 & Objectives & Ways to achieve them \\
\hline 1 & $\begin{array}{l}\text { Providing a high } \\
\text { quality health } \\
\text { service in a smooth } \\
\text { manner and } \\
\text { available to all } \\
\text { citizens at the } \\
\text { lowest cost. }\end{array}$ & $\begin{array}{l}\text { - providing the delivery services to all } \\
\text { targets of primary health care users. } \\
\text { - coverage increasing of vaccines } \\
\text { within the expanded program of } \\
\text { immunization. } \\
\text { - to cover all targeted in the mother } \\
\text { and child care program. } \\
\text { - Control of transitional diseases and } \\
\text { the Epidemiological Surveillance } \\
\text { Program. }\end{array}$ \\
\hline 2 & $\begin{array}{l}\text { Making } \\
\text { comprehensive } \\
\text { database on the } \\
\text { health of each } \\
\text { individual in the } \\
\text { community. }\end{array}$ & $\begin{array}{c}\text { - Automating all information about } \\
\text { primary health care programs and } \\
\text { establishing and updating a reliable } \\
\text { database. } \\
\text { - Using GIS software for spatial } \\
\text { signature of information on maps. }\end{array}$ \\
\hline 3 & $\begin{array}{l}\text { Spread health } \\
\text { awareness to all } \\
\text { groups of society. }\end{array}$ & $\begin{array}{l}\text { - Organizing seminars and lectures in } \\
\text { schools and places of worship and } \\
\text { distributing educational publications } \\
\text { with the participation of NGO. }\end{array}$ \\
\hline 4 & $\begin{array}{l}\text { Promote preventive } \\
\text { services to create a } \\
\text { sound environment } \\
\text { free from disease. }\end{array}$ & $\begin{array}{l}\text { - Early detection of high blood } \\
\text { pressure, diabetes and chronic } \\
\text { diseases. } \\
\text { - Early detection of mothers at risk. }\end{array}$ \\
\hline 5 & $\begin{array}{l}\text { Optimal investment } \\
\text { of human and } \\
\text { technical resources. }\end{array}$ & $\begin{array}{l}\text { - Increasing the efficiency and } \\
\text { awareness of health workers in the } \\
\text { field of primary health care. } \\
\text { - Setting the goals and tasks for each } \\
\text { individual within the health visitor } \\
\text { program. }\end{array}$ \\
\hline \multicolumn{3}{|c|}{$\begin{array}{l}\text { Reference : the two researchers depended on( An evaluation } \\
\text { study of the health visitor, Ministry of Health, General } \\
\text { Health Department in Maysan, Achievement booklet } \\
\text {,6:2015), (WHO, Geneva, 2016), USAID (PHCPI), 2014: }\end{array}$} \\
\hline
\end{tabular}

\section{Research Methodology}

\subsection{Research importance}

4.1.1 Theoretical level: The issue of quality of health service at the present time is the focus of the health sector staff, which is one of the sectors most need to quest and study. The research importance lies in the results that will be reached through the survey and put ideas and proposals which contribute to achieve the research objectives.

4.1.2 Practical level: The importance of research lies in the scarcity of studies and researches that deal with the quality of health service and evaluation of programs, especially the health visitor program, which is one of the leading studies in this field.

\subsection{Research Objectives}

The research aims to achieve the following objectives:

4.2.1 Evaluate the health visitor program in Maysan governorate in terms of the quality and comprehensiveness of the health service, according to a set of international and local standards and indicators extracted from the theoretical aspect of the research and identifying the weaknesses of the program. 


\section{International Journal of Science and Research (IJSR) \\ ISSN (Online): 2319-7064}

Index Copernicus Value (2016): 79.57 | Impact Factor (2015): 6.391

4.2.2 Demonstrate the possibility extent to which policies applied in the health visitor program can be adopted at all primary health care centers in Iraq.

\subsection{Research Method}

The two researchers adopted the case study program as the framework in which information and findings are organized.

\subsection{The research sample and community}

The research community included Maysan Health Directorate - Health Visitor Division. 53 patients were selected, $(43.4 \%)$ of males and $56.6 \%$ females.

\subsection{Statistical methods used}

For the purpose of analyzing research data, the SPSS V24 program was used, in which the percentages (percentages, frequencies, arithmetic mean, standard deviation, coefficient of variation, relative and moral importance) were obtained.

\section{Results and Discussion}

5.1 Determination of quality of health services by adopting the health visitor program from the viewpoint of (patients)

The questionnaire was used as a tool for measuring the quality of health service through five dimensions (reliability, guarantee, tangible, assurance, sympathy and responsiveness) by presenting the arithmetic mean to determine sample responses, standard deviations to estimate the extent of dispersion in the responses and difference coefficient to determine the degree of homogeneity in the answers and order of the research paragraphs, the relative importance of knowing the degree of interest of the research sample, the ranking according to the significance of the paragraphs, the statistical significance, and the use of percentages to determine the severity of the answer, depending on the Fifth Likert Scale in the responses of the sample and the answer level will be between (1-5) and on five levels according to categories and the categories are as shown in Table 3 as follows: -

Table 3: Fifth Likert Scale

\begin{tabular}{|c|c|c|c|c|}
\hline 1 & 2 & 3 & 4 & 5 \\
\hline Very low & Low & Medium & High & Very high \\
\hline
\end{tabular}

hypothetical mathematical mean $=\underline{\text { highest value }+ \text { lowest value }}$ 2

$=\frac{5+1}{2}=3$

\subsubsection{Reliability and warranty}

This dimension was measured by four paragraphs, as shown in Table (4). The results were divided between the highest response level achieved by paragraph.(1), where the highest mean (4.45) was obtained, which is higher than the mean of (3), which indicates the option (very high), and this indicates that the health visitor program staff update the database of patients in terms of housing information and the development of the condition constantly. Paragraph (2) achieved the lowest level of response. It obtained an average of 3.45, higher than the mean (3) with relative importance ( 69.06), due to the poor availability of medicines for patients in the recent period, forcing the patient to buy from outside the health center.

Table 4: Arithmetic mean, standard deviation, coefficient of variation, relative importance and order by significance and statistical significance of variables at sub-level and total reliability and guarantee

\begin{tabular}{|c|c|c|c|c|c|c|c|}
\hline No. & Paragraphs & Mean & S.D. & C.V. & $\begin{array}{l}\text { relative } \\
\text { importance }\end{array}$ & \begin{tabular}{c|c|}
$\begin{array}{c}\text { significance } \\
\text { level }\end{array}$ \\
\end{tabular} & $\begin{array}{c}\mathrm{P} \\
\text { Value }\end{array}$ \\
\hline 1 & $\begin{array}{l}\text { A field survey of your location and family data is conducted and } \\
\text { updated continuously. }\end{array}$ & 4.45 & 0.67 & 14.98 & 89.06 & 1 & 0.000 \\
\hline 2 & $\begin{array}{l}\text { The medicines prescribed by your doctor are dispensed by the } \\
\text { health center pharmacy. }\end{array}$ & 3.45 & 1.12 & 32.41 & 69.06 & 4 & 0.005 \\
\hline 3 & $\begin{array}{l}\text { The cost of health service provided through the program is suitable } \\
\text { for your monetary situation }\end{array}$ & 4.51 & 0.75 & 16.63 & 90.19 & 2 & 0.000 \\
\hline 4 & $\begin{array}{c}\text { The service you received is suitable to your expectations and } \\
\text { covers all your health needs. }\end{array}$ & 4.23 & 0.72 & 17.14 & 84.53 & 3 & 0.000 \\
\hline & General Total of Reliability and warranty & 4.16 & 0.49 & 11.85 & 83.21 & & 0.000 \\
\hline
\end{tabular}

\subsubsection{Response}

The response was measured in three main paragraphs, as shown in Table (5). The results yielded the highest level of response achieved by paragraph (5). It got the highest arithmetic mean reaches to (4.26), which is higher than the mean of (3), which refers to the option (very high), that reflects the interest of the health visitor program staff in answering the questions raised by the patients without delay, while paragraph (6) achieved the lowest level of response; it got an arithmetic mean of value 3,15 which is higher than the mean of (3), that refers to the option (average), and was asked about this by the program officials but the concerned authority in the province showed no-response after monitoring environmental problems by the mobile health visitor team.

Table 5: Arithmetic mean, standard deviation, coefficient of variation, relative importance and order according to importance and statistical significance of variables at sub-level and total of response

\begin{tabular}{|c|c|c|c|c|c|c|c|}
\hline No. & Paragraphs & Mean & S.D. & C.V. & $\begin{array}{c}\text { relative } \\
\text { importance }\end{array}$ & $\begin{array}{c}\text { significance } \\
\text { level }\end{array}$ & $\begin{array}{c}P \\
\text { Value }\end{array}$ \\
\hline 5 & $\begin{array}{c}\text { There is a quick response by the program staff to answer your } \\
\text { queries. }\end{array}$ & 4.26 & 0.84 & 19.59 & 85.28 & 1 & 0.000 \\
\hline
\end{tabular}

Volume 6 Issue 12, December 2017 


\section{International Journal of Science and Research (IJSR) \\ ISSN (Online): 2319-7064}

Index Copernicus Value (2016): 79.57 | Impact Factor (2015): 6.391

\begin{tabular}{|c|c|c|c|c|c|c|c|}
\hline 6 & $\begin{array}{c}\text { Environmental problems in your residential area are monitored by } \\
\text { the health visitor team. }\end{array}$ & 3.15 & 1.23 & 39.07 & 63.02 & 3 & 0.376 \\
\hline 7 & Health service is provided throughout the day and late hours. & 3.38 & 0.84 & 24.79 & 67.55 & 2 & 0.002 \\
\hline & General Total Response & 3.60 & 0.73 & 20.35 & 71.95 & & 0.000 \\
\hline
\end{tabular}

\subsubsection{Sympathy}

This dimension is measured by three paragraphs, as shown in Table (6). The results were divided between the highest level of response achieved by paragraph (9), it got the highest arithmetic mean (4.42) which is higher than the mean of (3) that refers to the (very high) option, because the optimal goal of the program is to provide health services to all groups of society without discrimination.

While paragraph (8) achieved the lowest level of response, obtained an arithmetic mean of 4.40 , which is higher than the satisfactory mean of (3).

Table 6: Arithmetic mean, standard deviation, coefficient of variation, relative importance and order by significance and statistical significance of variables at the total and sub-level of sympathy

\begin{tabular}{|l|l|l|l|l|l|l|l|}
\hline No. & Paragraphs & Mean & S.D. & C.V. & $\begin{array}{l}\text { relative } \\
\text { importance }\end{array}$ & $\begin{array}{l}\text { significance } \\
\text { level }\end{array}$ & $\begin{array}{l}\text { P } \\
\text { Value }\end{array}$ \\
\hline 8 & $\begin{array}{l}\text { The needs and wishes of the patient } \\
\text { are met in a spirit of friendliness and } \\
\text { kindness }\end{array}$ & 4.40 & 0.60 & 13.63 & 87.92 & 3 & 0.000 \\
\hline 9 & $\begin{array}{l}\text { All patients are treated equally } \\
\text { without any personal discrimination. }\end{array}$ & 4.42 & 0.57 & 12.90 & 88.30 & 1 & 2 \\
\hline 10 & $\begin{array}{l}\text { The patient's interest is placed at } \\
\text { the forefront of management and } \\
\text { program staff concerns }\end{array}$ & 4.28 & 0.57 & 13.25 & 85.66 & 0.000 & 0.000 \\
\hline & General total of sympathy & 4.36 & 0.45 & 10.30 & 87.30 & & 0.000 \\
\hline
\end{tabular}

\subsubsection{Tangible}

The results of measuring this dimension were obtained through the answers of the research sample for the four paragraphs that covered this dimension, as shown in Table (7). The results were divided between the highest level of response achieved by paragraph (11) which got the higher arithmetic mean of 4,64 which is higher than the satisfactory mean of (3), that indicates the option (very high). During the field visit to the health centers, there were leaflets and educational posters as well as seminars in health centers, schools and places of worship. This is what the program seeks to convey the health and guidance message to the community in all districts of the province to clarify the mechanism of work of the program , while paragraph (12) achieved the lowest level of response. It obtained an arithmetic mean of 3.11 , which is higher than the mean of (3), which indicates the option (average), and this is due to the establishment of the free visitor clinic Health center for early detection of chronic diseases within the work of the health visitor program in the evening.

Table 7: Arithmetic mean, standard deviation, coefficient of variation, relative importance and order by significance and statistical significance of variables at the total and sub-level of tangible

\begin{tabular}{|c|c|c|c|c|c|c|c|}
\hline No. & Paragraphs & Mean & S.D. & C.V. & relative importancesignificance level & $\begin{array}{c}\text { P } \\
\text { Value }\end{array}$ \\
\hline 11 & $\begin{array}{c}\text { The existence of educational and } \\
\text { awareness means about health services } \\
\text { (posters, leaflets, seminars ..) }\end{array}$ & 4.64 & 0.62 & 13.42 & 92.83 & 1 & 0.000 \\
\hline 12 & $\begin{array}{c}\text { Health visitor team visits your home for } \\
\text { early detection of diseases }\end{array}$ & 3.11 & 1.01 & 32.53 & 62.26 & 4 & 0.419 \\
\hline 13 & $\begin{array}{c}\text { Suitable and clean waiting rooms are } \\
\text { available in the health center that } \\
\text { applying the health visitor program. }\end{array}$ & 4.28 & 0.72 & 16.75 & 85.66 & 3 & 0.000 \\
\hline 14 & $\begin{array}{c}\text { Do you notice that your family has } \\
\text { improved health status after applying the } \\
\text { health visitor program in the province? }\end{array}$ & 4.00 & 0.62 & 15.50 & 80.00 & 2 & 0.000 \\
\hline & General total of tangible & 4.01 & 0.43 & 10.66 & 80.19 & & 0.000 \\
\hline
\end{tabular}

\subsubsection{Assurance (trust)}

The assurance (trust) dimension was measured by four paragraphs, as shown in Table (8). The results showed the highest level of response achieved by paragraph (15), which got the higher arithmetic mean of (4.60) which is higher than the mean of (3), that indicates the option (very high), because the success of the program is based on the integrity of the database of the citizen and is updated continuously and the two researchers noted the process of updating the family records and registers of health centers and electronic calculator, paragraph (17) has achieved the lowest level of answer, with a arithmetic mean of 4.08 , which is higher than the mean of (3), indicating a weakness in this field. 


\section{International Journal of Science and Research (IJSR) \\ ISSN (Online): 2319-7064 \\ Index Copernicus Value (2016): 79.57 | Impact Factor (2015): 6.391}

Table 8: Arithmetic mean, standard deviation, coefficient of variation, relative importance and order by significance and statistical significance of variables at the total and sub-level of assurance (Trust)

\begin{tabular}{|c|c|c|c|c|c|c|c|}
\hline No. & Paragraphs & Mean & S.D. & C.V. & $\begin{array}{c}\text { relative } \\
\text { importance }\end{array}$ & $\begin{array}{c}\text { significance } \\
\text { level }\end{array}$ & $\begin{array}{c}P \\
\text { Value }\end{array}$ \\
\hline 15 & $\begin{array}{c}\text { Family data and health status for each member of your family } \\
\text { are electronically documented at the health center. }\end{array}$ & 4.60 & 0.57 & 12.30 & 92.08 & 1 & 0.000 \\
\hline 16 & $\begin{array}{c}\text { You are given a full and complete explanation of your health } \\
\text { condition at each medical passage }\end{array}$ & 4.04 & 0.76 & 18.79 & 80.75 & 2 & 0.000 \\
\hline 17 & $\begin{array}{c}\text { Your health care provider will give you instructions on the use } \\
\text { of the medicine and its associated negative symptoms. }\end{array}$ & 4.08 & 0.98 & 23.99 & 81.51 & 4 & 0.000 \\
\hline 18 & $\begin{array}{c}\text { There is a high level of satisfaction with health services } \\
\text { provided by the Health Visitor Program }\end{array}$ & 4.13 & 0.83 & 20.16 & 82.64 & 3 & 0.000 \\
\hline & General total of assurance(Trust) & 4.21 & 0.60 & 14.32 & 84.25 & & 0.000 \\
\hline
\end{tabular}

All the dimensions of the main research mentioned above are important at patients, but to be judged at, varying and

depending on the scientific and cultural level, as shown in Table (9).

Table 9: The total results of the arithmetic mean, the standard deviation, the coefficient of difference and the order are according to the importance and the significance of the main dimensions of the research questionnaire.

\begin{tabular}{|c|c|c|c|c|c|c|}
\hline No. & Paragraphs & Mean & S.D. & C.V. & significance level & $\begin{array}{c}\text { P } \\
\text { Value }\end{array}$ \\
\hline 1 & empathy & 4.36 & 0.45 & 10.30 & first & 0.000 \\
\hline 2 & Tangible & 4.01 & 0.43 & 10.66 & Second & 0.000 \\
\hline 3 & Reliability and guarantee & 4.16 & 0.49 & 11.85 & Third & 0.000 \\
\hline 4 & Assurance (trust) & 4.21 & 0.60 & 14.32 & Fourth & 0.000 \\
\hline 5 & Response & 3.60 & 0.73 & 20.35 & Fifth & 0.000 \\
\hline & General & 4.08 & 0.38 & 9.22 & & 0.000 \\
\hline
\end{tabular}

Table (10) illustrates the percentages and frequencies of the research dimensions paragraph (reliability, guarantee, responsiveness, empathy, tangible and assurance (trust).

Table 10: Percentage and frequency of research dimensions

\begin{tabular}{|c|c|c|c|c|c|c|c|c|c|c|c|}
\hline \multirow[t]{2}{*}{ Dimensions } & \multirow[t]{2}{*}{ Question } & \multicolumn{2}{|c|}{$\begin{array}{c}\text { Very low } \\
1 \\
\end{array}$} & \multicolumn{2}{|c|}{$\begin{array}{c}\text { Low } \\
2 \\
\end{array}$} & \multicolumn{2}{|c|}{$\begin{array}{c}\text { Medium } \\
3 \\
\end{array}$} & \multicolumn{2}{|c|}{$\begin{array}{c}\text { High } \\
4\end{array}$} & \multicolumn{2}{|c|}{$\begin{array}{l}\text { Very high } \\
5\end{array}$} \\
\hline & & Freq. & $\%$ & Freq. & $\%$ & Freq. & $\%$ & Freq. & $\%$ & Freq. & $\%$ \\
\hline \multirow{4}{*}{$\begin{array}{l}\text { Reliability and } \\
\text { guarantee }\end{array}$} & $1 \mathrm{Q}$ & 0 & 0.00 & 1 & 1.89 & 2 & 3.77 & 22 & 41.51 & 28 & 52.83 \\
\hline & $2 \mathrm{Q}$ & 3 & 5.66 & 6 & 11.32 & 19 & 35.85 & 14 & 26.42 & 11 & 20.75 \\
\hline & $3 \mathrm{Q}$ & 0 & 0.00 & 1 & 1.89 & 5 & 9.43 & 13 & 24.53 & 34 & 64.15 \\
\hline & $4 Q$ & 0 & 0.00 & 1 & 1.89 & 6 & 11.32 & 26 & 49.06 & 20 & 37.74 \\
\hline \multirow[t]{3}{*}{ Response } & $5 \mathrm{Q}$ & 1 & 1.89 & 0 & 0.00 & 7 & 13.21 & 21 & 39.62 & 24 & 45.28 \\
\hline & $6 \mathrm{Q}$ & 5 & 9.43 & 11 & 20.75 & 18 & 33.96 & 9 & 16.98 & 10 & 18.87 \\
\hline & $7 \mathrm{Q}$ & 1 & 1.89 & 5 & 9.43 & 24 & 45.28 & 19 & 35.85 & 4 & 7.55 \\
\hline \multirow[t]{3}{*}{ Empathy } & $8 \mathrm{Q}$ & 0 & 0.00 & 0 & 0.00 & 3 & 5.66 & 26 & 49.06 & 24 & 45.28 \\
\hline & $9 Q$ & 0 & 0.00 & 0 & 0.00 & 2 & 3.77 & 27 & 50.94 & 24 & 45.28 \\
\hline & $10 \mathrm{Q}$ & 0 & 0.00 & 1 & 1.89 & 2 & 3.77 & 22 & 41.51 & 28 & 52.83 \\
\hline \multirow[t]{4}{*}{ Tangible } & $11 \mathrm{Q}$ & 3 & 5.66 & 6 & 11.32 & 19 & 35.85 & 14 & 26.42 & 11 & 20.75 \\
\hline & $12 \mathrm{Q}$ & 0 & 0.00 & 0 & 0.00 & 3 & 5.66 & 32 & 60.38 & 18 & 33.96 \\
\hline & $13 \mathrm{Q}$ & 0 & 0.00 & 1 & 1.89 & 1 & 1.89 & 14 & 26.42 & 37 & 69.81 \\
\hline & $14 \mathrm{Q}$ & 4 & 7.55 & 9 & 16.98 & 20 & 37.74 & 17 & 32.08 & 3 & 5.66 \\
\hline \multirow{4}{*}{$\begin{array}{l}\text { Assurance } \\
\text { (trust) }\end{array}$} & $15 Q$ & 0 & 0.00 & 1 & 1.89 & 5 & 9.43 & 25 & 47.17 & 22 & 41.51 \\
\hline & $16 \mathrm{Q}$ & 0 & 0.00 & 1 & 1.89 & 7 & 13.21 & 36 & 67.92 & 9 & 16.98 \\
\hline & $17 Q$ & 0 & 0.00 & 0 & 0.00 & 2 & 3.77 & 17 & 32.08 & 34 & 64.15 \\
\hline & $18 \mathrm{Q}$ & 0 & 0.00 & 1 & 1.89 & 11 & 20.75 & 26 & 49.06 & 15 & 28.30 \\
\hline
\end{tabular}

\section{Conclusions and Recommendations}

\subsection{Conclusions}

6.1.1 There is a reliable and up-to-date database that can be relied upon to identify health service targets and not only benefit the health sector, but also contribute to partnership with other sectors for getting accurate and up-to-date statistics and information.
6.1.2 Absence of measures taken by the Ministry of Health and the municipal councils in the province about what was detected regarding the environmental problems in residential areas by the mobile health visitor teams.

6.1.3 The program addressed the problem of vaccine dropouts through the activation of the expanded immunization program and linking it to the system of sending SMS messages to follow up the vaccines, as well as through mobile health visitor teams.

\section{Volume 6 Issue 12, December 2017}




\section{International Journal of Science and Research (IJSR) \\ ISSN (Online): 2319-7064 \\ Index Copernicus Value (2016): 79.57 | Impact Factor (2015): 6.391}

6.1.4 Achieving a high level of satisfaction with the quality of health services provided by the health visitor program, as confirmed by the results of the research and the views of patients during the filling of the questionnaire during the field visit.

6.1.5 The contribution of the health visitor program to raise the awareness of the health of the community through its educational seminars held in primary health care centers, places of worship and schools.

\subsection{Recommendations}

6.2.1 The Ministry of Health should adopt the health visitor program development project because of the great advantages it has provided through the clear impact on the performance of the primary health care centers in general and on the quality of the health service provided in particular and its financial support.

6.2.2 Informing the Ministry of Health of the need to spread awareness of quality, concepts and applications to the health sector services in general and to the services provided by the health visitor program in particular, for the health education, and to change the ideas and habits and focus on correct behaviors.

6.2.3 Emphasize the parties concerned with environmental issues related to public health in residential areas in the province to take the necessary action after being monitored by the mobile health visitor team.

6.2.4 Establish training programs for the employees of the health visitor program periodically and on a regular basis , in order to develop their skills in (how to deal with advanced software, how to deal with patients, convince them to receive health services and achieve quality in providing health services.

\section{References}

[1] Khoja, Tawfiq, 2003, Introduction to Quality Improvement for Primary Health Care, Dar Al Shorouk for Publishing and Distribution, Amman, Jordan: 159158

[2] Madhi, Mohammed Toufik, (2002), Comprehensive Quality Management Applications in Modern Organizations in the Field of Health and Education, Proposed Concept Model, Cairo, Egypt, Arab Organization for Administrative Development Publications.

[3] Jauda, Mahfouz Ahmed, (2010), Comprehensive Quality Management Concepts and Applications, Dar Wael Publishing, Amman, Jordan.

[4] Idris, Thabet Abdel Rahman, (2006), Efficiency and Quality of Logistics Services, Basic Concepts and Methods of Measurement and Evaluation, University House, Alexandria.

[5] Al-Mahyawi, Qassim Nayef Alwan, (2006), Quality Management in Services, Concepts, Operations and Applications, Dar Al Shorouk for Publishing and Distribution, Amman, Jordan.
[6] Madkour, Fawzi Shaaban, (1998), Marketing Health Services, Cairo: ITRAK for Publishing and Distribution.

[7] Jad Al-Rab, Saed Mohamed, (2008), Recent Trends in the Management of Health Organizations, Suez Canal University, Egypt.

[8] Almusaed, Zaki Khalil, (2005), Marketing and Applications of Services, Dar Al-Manhej for Publishing and Distribution, First Edition, Amman.

[9] Abu Haseera, Maysa Fathi Eid, (2016), Evaluation of the Performance Quality of Government Health Institutions in accordance with world health organization (WHO) Standards, Master Thesis, College of Commerce, Islamic University, Gaza.

[10] Aloraibi, Zamil shyia, (2008),Brochure of the national project of the health visitor program, Maysan Health Directorate.

[11] Evaluation study on the health visitor program, Ministry of Health, General Health Department.

[12] Al-Munjaz booklet, Maysan Health Directorate, 2015

[13] Obaidat, Thouqan, and Adas, Abdul Rahman, and Abdul Haq, Kayed, (2001), Scientific Research: Its Concept, Tools and Methods, Dar Al Fikr Publishing and Distribution, Amman.

[14] Annual report of the Iraqi Ministry of Health, 2015.

[15] World Health Organization, 'World Health Statistics: Monitoring for the MDGs', WHO, Geneva, 2016.

[16] Baseline assessment report 2011, USAID Primary Health Care Project in Iraq (PHCPI) .

[17] USAID/PRIMARY HEALTH CARE PROJECT IN IRAQ (USAID/PHCPI), Annual Report,2012.

\section{Author Profile}

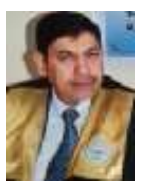

Ghani dahham tanai al-zubaidi $\mathrm{Ph} . \mathrm{D}$ in Business Administration since 2004, specialization in human resources management, Professor in the Department of Business Administration ,Faculty of Management and Economics - University of Baghdad. Has more than 16 research published in Iraqi scientific journals

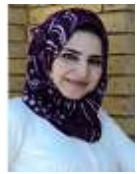

Rawaa Abd Al-Qader Al-kaisi holds a Master's degree in Business Administration - Performance evaluation from the University of Baghdad -2017, working in Ministry of Health, General Inspector Office. She has two published research. 